\title{
PENGARUH PERAN AYAH (FATHERING) TERHADAP DETERMINASI DIRI (SELF DETERMINATION) REMAJA
}

\author{
Leli Nailul Muna \\ Elok Halimatus Sakdiyah \\ Fakultas Psikologi \\ Universitas Islam Negeri Maulana Malik Ibrahim Malang
}

\begin{abstract}
ABSTRAK : Tujuan dalam penelitian ini adalah untuk mengetahui apakah peran ayah berpengaruh terhadap determinasi diri pada remaja kelas X di SMAN 3 Malang. Responden dalam penelitian ini berjumlah 108 orang dengan 54 orang laki-laki dan 54 perempuan. Metode penelitian data menggunakan metode kuantitatif dengan kuesioner terbuka. Teknik pengambilan sampel menggunakan teknik purposive sampling, dengan kriteria responden hanya anak yang tinggal bersama ayah dan ibu kandung yang menjadi sampel dalam penelitian ini. Skala peran ayah disusun sendiri oleh peneliti dan skala determinasi diri diadaptasi dari skala Basic Psychological Needs scale milik Ryan\& Deci.

Hasil analisis data menunjukkan bahwa peran ayah berpengaruh positif terhadap determinasi diri dengan nilai $p=0.000$ dan nilai $R 0,37$. Hasil penelitian juga menemukan bahwa peran ayah sebagai pemberi perhatian dan kasih sayang (caregiver) berpengaruh terhadap rasa kemandirian (autonomy) dengan nilai $p=0,008$, peran ayah sebagai konsultan dan penasihat (advocate) berpengaruh terhadap rasa kompetensi (competence) dengan nilai $p=0,04$, dan peran ayah sebagai sumber daya sosial dan akademik (resource) berpengaruh terhadap rasa keterhubungan (relatedness) remaja dengan nilai $p=0,008$. Penelitian ini juga menunjukkan bahwa peran ayah pada anak perempuan dan anak laki-laki tidak berbeda.
\end{abstract}

Kata Kunci : Fathering, Self Determination, Remaja

PSIKOISLAMIKA. Jurnal Psikologi Islam (JPI) copyright @ 2015 Pusat Penelitan dan Layanan Psikologi. Volume 12 Nomor 1 Tahun 2015

\section{PENDAHULUAN}

Remaja masa kini menghadapi tuntutan dan harapan, juga bahaya serta godaan, yang tampaknya lebih banyak dan kompleks dibandingkan remaja generasi yang lalu. Dukungan keluarga dan sosial yang tidak efektif membuat remaja tidak memperoleh cukup kesempatan dan dukungan untuk menjadi orang dewasa yang kompeten. Hal ini bisa menjadi faktor risiko bagi perkembangan remaja yang sehat. Data menunjukkan remaja Indonesia saat ini mengalami kemunduran secara moral, budi pekerti dan kematangan emosi, yang dapat dilihat dari semakin banyaknya kasus pergaulan bebas, gaya hidup yang ke barat-baratan, narkoba dan kasus-kasus depresif seperti percobaan bunuh diri dan lain sebagainya. Beberapa data mengenai perilaku maladaptif remaja menunjukkan dari 2,4 juta perempuan yang melakukan aborsi, 700-800 ribu adalah remaja, dari 1283 kasus HIV/AIDS, diperkirakan 52.000 terinfeksi dimana $70 \%$ adalah remaja (BKKBN, 2011).

Selain masa remaja sebagai masa yang sarat dengan bahaya dan godaan, masa remaja juga merupakan masa untuk mengeksplorasi sebanyak mungkin potensi positif mereka. Pada masa ini remaja memang dituntut untuk mengembangkan diri sebaik mungkin sebagai bekal mereka memasuki masa dewasa. Pencapaian akademik juga menjadi fokus pada masa remaja.

Menurut Erikson, Hill, dan Holmbeck dalam penelitian Soenens dan Vansteenkiste bahwa berkaitan dengan tugas perkembangan, tugas perkembangan 
remaja berpusat pada isu-isu mengenai individuasi dan kemandirian (Soenens \& Marteen, 2010). Kebutuhan mandiri merupakan salah satu aspek yang penting dalam determinasi diri. Determinasi diri dalam konteks teori determinasi diri adalah sebuah pendekatan terhadap motivasi dan kepribadian manusia yang menyoroti pentingnya perkembangan sumber daya manusia bagi perkembangan kepribadian dan regulasi diri (Ryan, \& Deci, 2006). Teori determinasi diri menyatakan bahwa ketika perilaku mengikuti kebutuhan akan kompetensi, otonomi, dan keterhubungan, maka individu mengalami motivasi intrinsik, namun ketika perilaku menunjukkan keinginan pemenuhan nilai lain seperti reputasi, uang, persetujuan, maka perilaku termotivasi secara ekstrinsik (Deci \& Ryan, 2000).

Meskipun menurut teori determinasi diri individu secara alami akan mengatur diri dan bertindak sesuai nilai-nilai dan keinginan mereka, lingkungan sosial dapat dengan mudah mengurangi fungsi kemandirian seseorang (Deci \& Ryan, 2008). Menurut Grolnick (dalam Deci \& Marteen, 2004) ketika seorang remaja diasuh secara tidak konsisten dan dikontrol secara berlebihan, pengaturan determinasi diri mereka akan terhambat. Sebaliknya orangtua dan guru yang sensitif akan kebutuhan anak-anaknya dan mampu memberikan pilihan diharapkan akan membangun perasaan mandiri dan choicefulness anak sehingga anak akan lebih sehat menangani lingkungannya.

Berkaitan dengan peran orangtua dalam pengasuhan, peran ibu masih seringkali menjadi perhatian utama saat topik mengenai keluarga dan anak diangkat. Keyakinan bahwa anak adalah urusan ibu bukan hanya keyakinan masyarakat Indonesia saja, melainkan bersifat universal di berbagai budaya di dunia ini. Peran ayah seringkali terlupakan, karena ayah lebih diarahkan pada peran pemenuhan kebutuhan ekonomi. Penelitian Andayani \& Koencoro (2007) masih memberikan gambaran bahwa peran ayah cenderung rendah dalam proses pengasuhan, ayah cenderung menjaga jarak dari anak-anaknya.

Dalam beberapa penelitian lain juga ditemukan bahwa ayah dan ibu memiliki cara yang berbeda dalam mempengaruhi anak-anaknya. Michael Yogman dan rekannya (dalam Dagun, 2002) meneliti perbedaan cara bermain ayah dan ibu. Ditemukan bahwa ayah cenderung kurang banyak mengucapkan kata-kata tetapi ia lebih sering memegang bayinya. Memegang, mengajak bermain dan menimang-nimang dengan pola ritme gerak. Ayah lebih banyak memperlihatkan aktivitas fisik, sedangkan ibu memperlihatkan cara konvensional, dengan berusaha menarik perhatian anak dengan menggoyangkan boneka di depan bayi dan mengajak berbicara.

Dalam konteks remaja, Nugent (dalam Susanto, 2013) melaporkan bahwa remaja yang mendapatkan dukungan dan adanya komunikasi yang intensif dengan ayahnya memiliki kebebasan yang lebih besar untuk berusaha bereksplorasi untuk menjadi dirinya sendiri, menemukan jati dirinya, mencoba kemampuan dirinya, memperkuat penilaiannya sendiri terhadap pilihan-pilihan yang dibuat dan mempertimbangkan kemungkinannya menghadapi orang lain dalam merencanakan masa depannya. Selain itu, Videon (dalam Susanto, 2013) beranggapan bahwa keterlibatan ayah dalam kehidupan remaja akan mempengaruhi mereka dalam hubungannya dengan teman sebaya dan prestasi disekolah, serta membantu remaja dalam mengembangkan pengendalian dan penyesuaian diri dalam lingkungannya.

Dari beberapa penelitian dan kajian-kajian mengenai peran ayah dalam perkembangan anak, peneliti tertarik untuk meneliti bagaimana pengaruh peran ayah dalam membangun determinasi diri remaja, mengingat ayah merupakan agen sosial yang paling dekat dengan anak selain ibu, yang akan memberikan pengaruh terhadap warna perkembangan seorang anak remaja. Pemilihan determinasi diri didasarkan atas pertimbangan bahwa determinasi diri merupakan salah satu aspek psikologis penting bagi kesehatan dan kesejahteraan hidup manusia.

Penelitian ini diharapkan dapat memberi manfaat teoritis maupun praktis berkaitan dengan proses pengembangan determinasi diri remaja berdasarkan peran keterlibatan ayah dalam pengasuhan.

\section{KAJIAN PUSTAKA \\ Peran Ayah (Fathering)}

Peran ayah (fathering) adalah peran yang dimainkan seorang ayah dalam kaitannya dengan tugas untuk mengarahkan anak menjadi mandiri dan berkembang secara positif, baik secara fisik dan psikologis (Hart, dalam Yuniardi, 2009). Peran ayah sama pentingnya dengan peran ibu dan memiliki pengaruh pada perkembangan anak walau pada umumnya menghabiskan waktu relatif lebih sedikit dengan anak dibandingan dengan ibu (Lamb, 2010).

Dari review yang dilakukan Doherty, dkk (dalam Andayani \& Koencoro, 2007) menemukan 
ada lima faktor yang mempengaruhi peran ayah dalam pengasuhan, yakni: faktor ibu, faktor ayah sendiri, faktor anak, faktor coparental dan faktor kontekstual. Semua faktor saling mempengaruhi satu sama lain. Dalam penelitian Simons, dkk ditemukan bahwa sikap, harapan dan dukungan ibu terhadap ayah akan mempengaruhi keterlibatan ayah pada anaknya. Ayah yang merasa diberikan dukungan oleh istrinya dan dinilai mampu melakukan pengasuhan akan terlibat lebih banyak dalam mengasuh anak (Pasley, dkk, dalam Andayani \& Koencoro, 2007).

Teori Hart (Yuniardi, 20009) membagi peranan ayah dalam pengasuhan kedalam delapan aspek, yakni:

(1) Economic Provider

(2) Friend and Playmate

(3) Caregiver

(4) Teacher and Role Model

(5) Monitor and Disciplinarian

(6) Protector

(7) Advocate

(8) Resource

Selanjutnya, National Center on Father and Families (Lamb, 2010) mengembangkan indikator ayah sebagai kerangka kerja/alat untuk penelitian kuantitatif maupun kualitatif sebagai berikut: (1) father presence - engagement, availability and responsibility; (2) care-giving - nurturance and maintenance of child's well-being, health and appearance; (3) social competence - efforts to develop and enhance child's social competence and academic achievement; (4) cooperative parenting - parents and other caregivers have a supportive, interdependent relationship aimed at optimal child development; (5) fathers' healthy living serving as a role model through healthy lifestyle, education and appropriate social behaviors; and (6) material and financial contributions - engaging in consistent activities that provide material and financial support to children.

\section{Determinasi Diri}

Teori determinasi diri adalah sebuah pendekatan terhadap motivasi dan kepribadian manusia yang menyoroti pentingnya perkembangan sumber daya manusia bagi perkembangan kepribadian dan regulasi diri (Ryan, \& Deci, 2006). Dalam definisi lain, teori determinasi diri adalah teori yang mengkaji tentang motivasi manusia dengan mempertimbangkan adanya kebutuhan psikologis bawaan yakni kompetensi, kemandirian dan keterhubungan (Ryan, \& Deci, 2000).
Titik awal konsep determinasi diri menyatakan bahwa manusia bersifat aktif, dimana mereka berorientasi pada pertumbuhan pribadi, dan secara alami mengintegrasikan diri kepada kesatuan diri dan mengintegrasikan diri dalam suatu sistem sosial yang lebih besar. Inti dari teori determinasi diri mengemukakan bahwa individu memiliki tiga kebutuhan psikologis yakni kompetensi, kemandirian dan keterhubungan. Kebutuhan ini bersifat universal yang berfungsi menunjang perkembangan psikologis dan kesehatan mental individu. Kebutuhan ini tidak dipelajari namun secara alami sudah melekat pada manusia tidak terbatas gender, budaya dan waktu (Chirkov, Ryan, Kim, \& Kaplan, dalam Deci dan Marteen, 2004)

\section{Dimensi determinasi diri (Deci \& Ryan, 2000):}

1. Kompetensi (Competence)

Kebutuhan kompetensi berfokus pada keinginan untuk bertindak efektif dalam menghadapi lingkungan. Kebutuhan kompetensi membuat individu lebih tertarik, terbuka, dan belajar lebih baik dalam beradaptasi dengan tantangan baru.

2. Kemandirian (Autonomy)

Kemandirian (autonomy) secara etimologis berarti mengatur diri sendiri, mandiri, teori determinasi diri menilai kemandirian (autonomy) sebagai kunci dalam memahami kualitas regulasi perilaku individu.

3. Keterhubungan

Kebutuhan keterhubungan (relatedness) berfokus pada kecenderungan universal untuk untuk berinteraksi, merasa terhubung, merasa terlibat, dan untuk merasakan pengalaman kasih sayang dan kepedulian terhadap orang lain. Kebutuhan keterhubungan (relatedness) dapat menjadi sarana internalisasi perilaku dan nilai melalui kelompok sosial.

Ketiga dimensi ini, secara alami akan mengalami perkembangan dan menuju determinasi diri, namun lingkungan sosial dapat menjadi penghambat pertumbuhan determinasi diri melalui kontrol, kritik, dan penolakan lingkungan social. Untuk mendukung pertumbuhan determinasi diri individu secara eksternal diperlukan lingkungan sosial yang mendukung. 


\section{Hipotesis}

Hipotesis Terarah: Ada pengaruh positif peran ayah terhadap determinasi diri pada remaja.

\section{METODE}

Variabel Penelitian

Variabel Bebas: Peran Ayàh

Variabel Tergantung: Determinasi Diri

Populasi dan Sampel

Populasi dalam penelitian ini adalah siswa kelas $X$ di SMAN 3 Malang yang berjumlah 212 orang. Teknik sampling yang digunakan adalah purposive sampling, dengan kriteria hanya remaja yang tinggal bersama ayah dan ibu kandung yang menjadi responden dalam penelitian ini. Dari 128 data yang terkumpul, ada 108 responden yang memenuhi kriteria untuk menjadi sampel dalam penelitian ini.

Metode Pengumpulan Data dan Teknik Analisa Data

Metode yang digunakan dalam pengambilan data adalah dengan menggunakan skala/kuisioner. Teknik analisa data dengan menggunakan uji regresi berganda, dengan program SPSS (Statistical Product and Service Solution) 16.0 for Windows.

\section{HASIL}

Signifikansi pengaruh variabel $x$ (peran ayah) terhadap variabel y (determinasi diri) adalah sebagai berikut:

Tabel 4.1 Hasil Uji Regresi Sederhana

\begin{tabular}{llll}
\hline Signifikansi & R Square & $t$ & $F$ \\
\hline 0,000 & 0,37 & 4,102 & 16,829 \\
\hline
\end{tabular}

Nilai ini menunjukkan bahwa peran ayah berpengaruh terhadap variabel determinasi diri, sehingga hipotesis peneliti diterima.

Gambar 4.1 Pengaruh aspek peran ayah terhadap determinasi diri

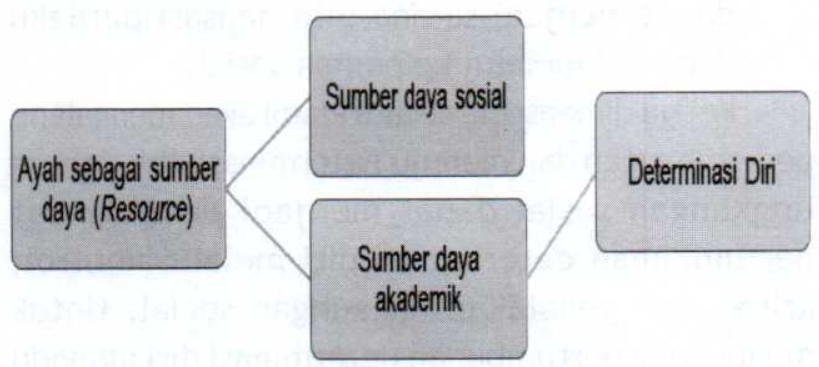

Dari nilai signifikansi, hanya aspek ayah sebagai sumber daya sosial dan akademik (resource) yang secara signifikan mempengaruhi determinasi diri. Dari nilai pearson correlation, ayah sebagai sumber daya sosial akademik (resource) berkorelasi sedang dengan determinasi diri, ayah sebagai konsultan dan penasihat (advocate), ayah sebagai guru dan teladan (teacher and role model), ayah sebagai pemberi perhatian dan kasih sayang (caregiver) menunjukkan korelasi yang lemah dengan determinasi diri. Ayah sebagai pelindung (protector) dan penegak disiplin (monitor and diciplinarian) menunjukkan hubungan yang sangat lemah dengan determinasi diri.

Selanjutnya, analisis pengaruh aspek peran ayah terhadap setiap aspek determinasi diri, sebagai berikut:

Tabel 4.2 Pengaruh Setiap Aspek

\begin{tabular}{|c|c|c|c|}
\hline \multirow{2}{*}{ Peran Ayah } & \multicolumn{3}{|c|}{ Signifikansi } \\
\hline & Kemandirian & Kompetensi & Keterhubungan \\
\hline $\begin{array}{l}\text { Pen yedia } \\
\text { E kon o m i } \\
\text { (Economic } \\
\text { Provider) }\end{array}$ & .266 & .753 & .414 \\
\hline $\begin{array}{l}\text { Teman (Friend } \\
\text { and Playmate) }\end{array}$ & .101 & .794 & .692 \\
\hline $\begin{array}{l}\text { P e m b e r i } \\
\text { Perhatian dan } \\
\text { Kasih Sayang } \\
\text { (Caregiver) }\end{array}$ & .008 & .385 & .988 \\
\hline $\begin{array}{l}\text { Gunu dan Teladan } \\
\text { (Teacher and } \\
\text { Role Model) }\end{array}$ & .739 & .749 & 1.000 \\
\hline $\begin{array}{l}\text { Pelind ung } \\
\text { (Protector) }\end{array}$ & .400 & .594 & .189 \\
\hline $\begin{array}{l}\text { Penegak disiplin } \\
\text { (Monitor and } \\
\text { Diciplinarian) }\end{array}$ & .341 & .164 & .995 \\
\hline $\begin{array}{l}\text { Konsult a n } \\
\text { dan Penasihat } \\
\text { (Advocate) }\end{array}$ & .445 & .041 & .878 \\
\hline $\begin{array}{l}\text { Sumber Daya } \\
\text { Sosial dan } \\
\text { Akade mik } \\
\text { (Resource) }\end{array}$ & .094 & .796 & .008 \\
\hline
\end{tabular}

Tabel diatas menunjukkan bahwa peran ayah sebagai pemberi perhatian dan kasih sayang (caregiver) berpengaruh terhadap kemandirian anak. Peran ayah sebagai konsultan dan penasihat (advocate) berpengaruh terhadap kompetensi anak, dan peran ayah sebagai sumber daya sosial dan akademik (resource) berpengaruh terhadap rasa keterhubungan anak.

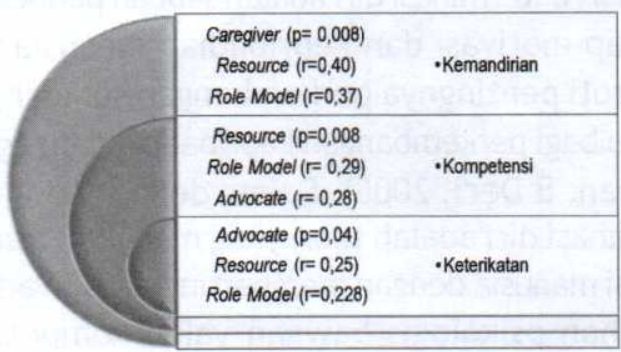

Gambar 4.2 Pengaruh peran ayah terhadap aspek determinasi diri 
Tabel 4.3 Hasil Uji T

\begin{tabular}{|c|c|c|c|}
\hline Variabel & $\begin{array}{l}\text { Signifikansi } \\
\text { (p) }\end{array}$ & Mean & Kesimpulan \\
\hline Peran ayah & 0,234 & $\begin{array}{l}\text { L } \quad K \quad: \\
182,30 \\
\text { P: } 187,35\end{array}$ & $\begin{array}{l}\text { Perempuan dan } \\
\text { Laki-laki memiliki } \\
\text { tidak perbedaan } \\
\text { signifikan dalam } \\
\text { peran ayah }\end{array}$ \\
\hline $\begin{array}{l}\text { Determinasi } \\
\text { diri }\end{array}$ & 0,370 & $\begin{array}{l}\text { LK: } 66,94 \\
\text { P: } 65,72\end{array}$ & $\begin{array}{l}\text { Perempuan } \\
\text { dan laki-laki } \\
\text { tidak memiliki } \\
\text { perbedaa n } \\
\text { signifikan dalam } \\
\text { determinasi diri }\end{array}$ \\
\hline $\begin{array}{l}\text { Determinasi } \\
\text { diri }\end{array}$ & 0,370 & $\begin{array}{l}\text { L } \quad K \quad: \\
66,94 \\
P: 65,72\end{array}$ & $\begin{array}{l}\text { Perempuan } \\
\text { dan laki-laki } \\
\text { tidak memiliki } \\
\text { perbedaan } \\
\text { signifikan dalam } \\
\text { determinasi } \\
\text { diri }\end{array}$ \\
\hline
\end{tabular}

Tabel di atas menunjukkan peran ayah dan determinasi diri tidak berbeda secara signifikan pada remaja laki-laki dan remaja perempuan. Namun peneliti akan menampilkan rata-rata (mean) peran ayah pada remaja laki-laki dan perempuan.

\section{PEMBAHASAN}

Hasil penelitian ini menemukan bahwa peran ayah dalam pengasuhan memberikan pengaruh positif, dengan nilai korelasi sebesar nilai $R$ 0,$37 ; p=0.000$ terhadap determinasi diri pada remaja SMA kelas X di SMAN 3 Malang. Dalam hasil penelitian ini ditemukan bahwa peran ayah yang paling berpengaruh terhadap determinasi diri adalah peran ayah sebagai sumber daya sosial dan akademik (resource) bagi anak, sedangkan peran ayah yang paling kecil memberikan pengaruh bagi determinasi diri adalah peran ayah sebagai pengawas dan penegak disiplin (monitor dan diciplinarian).

Selanjutnya ada tiga aspek penting yang merupakan aspek pembangun determinasi diri yakni, kebutuhan kemandirian (autonomy), kebutuhan kompetensi (competence), dan kebutuhan keterhubungan (relatedness). Peran ayah sebagai sumber daya sosial dan akademik (resource) secara signifikan memberikan pengaruh terhadap munculnya rasa keterhubungan para responden dengan lingkungan sekitar mereka. Ayah yang mejadi penghubung anak dalam dunia sosial dan memberikan dukungan akademik dapat membantu anak untuk memenuhi kebutuhan keterhubungan (relatedness) mereka dengan dunia sosial.

Selanjutnya, peran ayah sebagai pemberi perhatian dan kasih sayang (caregiver) memberikan pengaruh terhadap rasa kemandirian anak. Ketika ayah menunjukkan perhatian dan kasih saying, maka anak mengembangkan rasa kemandirian mereka, perasaan bahwa mereka dipercaya, diberikan kebebasan untuk memilih dan memutuskan sesuatu sesuai dengan minat mereka.

Peran ayah sebagai konsultan dan penasihat (advocate) berpengaruh terhadap terbentuknya rasa kompetensi anak. Ayah yang menyediakan waktu dan energinya untuk mendengarkan dan berbagi informasi kepada anak akan membantu anak mengembangkan rasa kompetensi mereka.

Temuan lainnya dalam penelitian ini menunjukkan bahwa ayah tidak berbeda dalam memperlakukan anak laki-laki dan anak perempuan, walaupun secara rata-rata (mean) peran ayah lebih tinggi pada anak perempuan dibandingkan anak laki-laki, terutama dalam peran ayah sebagai pemberi perhatian dan kasih sayang (caregiver), ayah sebagai pelindung (protector), dan ayah sebagai pengawas dan penegak disiplin (monitor and diciplinarian), sedangkan peran ayah sebagai konsultan dan penasihat (advocate) lebih tinggi pada anak laki-laki dibandingkan pada anak perempuan.

\section{KESIMPULAN}

a. Peran ayah dalam pengasuhan memberikan pengaruh terhadap determinasi diri pada remaja SMA kelas $X$ di SMAN 3 Malang

b. Peran ayah sebagai sebagai sumber daya sosial dan akademik (resource) berpengaruh paling kuat terhadap determinasi diri remaja, sedangkan peran ayah sebagai sebagai pengawas dan penegak disiplin (monitor dan disciplinarian) paling lemah pengaruhnya bagi determinasi diri remaja

c. Peran ayah sebagai sumber daya sosial dan akademik (resource) secara signifikan memberikan pengaruh terhadap munculnya rasa keterhubungan para responden dengan lingkungan sekitar mereka. Peran ayah sebagai pemberi perhatian dan kasih sayang (caregiver) memberikan pengaruh terhadap rasa kemandirian anak. Peran ayah sebagai konsultan dan penasihat (advocate) berpengaruh terhadap terbentuknya rasa kompetensi anak.

d. Ayah tidak berbeda dalam memperlakukan anak laki-laki dan anak perempuan, walaupun secara rata-rata (mean) peran ayah lebih tinggi pada anak perempuan dibandingkan anak laki-laki, terutama dalam peran ayah sebagai pemberi perhatian dan kasih sayang (caregiver), ayah 
sebagai pelindung (protector), dan ayah sebagai pengawas dan penegak disiplin (monitor and diciplinarian), sedangkan peran ayah sebagai konsultan dan penasihat (advocate) lebih tinggi pada anak laki-laki dibandingkan pada anak perempuan.

\section{SARAN}

a. Remaja diharapkan mampu membangun determinasi diri dengan meningkatkan rasa kemandirian, kompetensi, dan keterhubungan.

\section{DAFTAR PUSTAKA}

Andayani, Budi \& Koentjoro. (2007). Psikologi Keluarga: Peran Ayah Menuju Parenting. Sidoarjo: Laros

BKKBN. Fenomena Kenakalan Remaja di Indonesia. September 2011. ntb.bkkbn.go.id [Diakses Pada 27 Oktober 2014].

Dagun, Save M. (2002). Psikologi Keluarga. Jakarta: PT. Asdi Mahasatya

Deci, Edward L \& Maarten Vansteenkiste. (2004). Self Determination Theory and Basic Need Satisfaction: Understanding Human Development in Positive Psychology. Ricerche di Psicologia, Vol 27, No. 1.

Deci, Edward L\& Richard M.Ryan. (2000). The "What" and "Why" of Goal Pursuits: Human Needs and the Self-Determination of Behaviour. Journal Psychological Inquiry, Vol.11, No.4, 227-268.

Deci, Edward L \& Richard M.Ryan. (2008). SelfDetermination Theory: A Macrotheory of Human Motivation Development, and Health. Journal Canadian Psychology, Vol.49, No.3, 182-185.

Deci, Edward L, dkk. (1991). Motivation and Education: The Self-Determination Perspective. Journal Educational Psychology, vol.26, no.3\&4,
Karena aspek-aspek determinasi diri tersebut dapat menumbuhkan motivasi intrinsik dalam berperilaku. Ayah diharapkan dapat lebih terlibat dalam pengasuhan remaja, terutama pada peran ayah sebagai sumber resource, caregiver, dan advocate

b. Penelitian ini dilakukan menggunakan metode kuantitatif, untuk penelitian selanjutnya dapat lebih dikembangkan menggunakan penelitian tindakan maupun kualitatif.

325-346.

Lamb, Michael E. (2010). The Role Of The Father In Child Development, $5^{\text {th }}$ Ed. New Jersey: John Wiley \& Sons, Inc.

Ryan, Richard M \& Edward L. Deci. (2000). Self Determination Theory and the Facilitation of Intrinsic Motivation, Social Development, and Well-Being. Journal American Psychologist, Vol. 55, No. 1, 68-78.

Ryan, Richard M \& Edward L.Deci. (2006). Self Regulation and the Problem of Human Autonomy Does Psychology Need Choice, Self-Determination, and Will?. Journal of Personality, 74:6.

Soenens, Bart \& Maarten Vansteenkiste. (2010). A Theoritical Upgrade of the Concept of Parental Psychological Control: Proposing New Insights on the Basis of Self Determination Theory. Developmental Review, 30.

Susanto, Dedy. (2013). Keterlibatan ayah dalam pengasuhan, kemampuan coping dan resiliensi remaja. Jurnal Sains Dan Praktik Psikologi Magister Psikologi UMM, ISSN: 2303-2936 Vol. I (2), 101 - 113.

Yuniardi, Salis. (2009). Penerimaan Remaja Laki - Laki Dengan Perilaku Antisosial Terhadap Peran Ayahnya Di Dalam Keluarga. Laporan Penelitian Lembaga Penelitian Universitas Muhammadiyah Malang. 